\title{
Editorial
}

\section{Management of hypertension in pregnancy}

Hypertensive disorders of pregnancy (HDP) constitute one of the leading causes of pregnancy related adverse outcomes worldwide (1). It has been estimated that HDP complicates up $5-10 \%$ of all pregnancies and this situation might worsen as a result of advanced age at first pregnancy and increased prevalence of obesity and other cardiometabolic risk factors among women of childbearing age $(2,3)$.

Affected women are also at increased risk for cardiovascular disease (CVD) later in life, independently of traditional cardiovascular disease risks (4).

In the primary healthcare setting prevention, timely diagnosis, and treatment of HDP are associated with reduced maternal, fetal and neonatal morbidity and mortality. Many international and national clinical practice guidelines and scientific statement have been published on this topic. The last one was Hypertension in Pregnancy: Diagnosis, Blood Pressure Goals, and Pharmacotherapy: A Scientific Statement from the American Heart association (AHA) in December 2021 (5).

Here we summarize the European Society of Cardiology (ESC) and the AHA scientific statement key diagnostic and treatment approaches to management HDP (Table 1).

ESC guideline for the management of cardiovascular diseases during pregnancy presents only a few focused recommendations in chapter Hypertensive disorders (7). The Scientific Statement from the American Heart Association is based on report of the American College of Obstetricians and Gynecologists task force on hypertension on pregnancy.

Analysis revealed consistency for the definitions of hypertension on pregnancy, chronic and gestational hypertension, and the preventive strategies of a low dose aspirin for women at increased risk of preeclampsia, antihypertensive treatment of hypertension, delivery for women with preeclampsia. Significant variations include: different aspirin doses for prophylaxis of eclampsia, definitions of preeclampsia that reflect evolving of the multisystem nature of the disease, different antihypertensive treatment thresholds and targets among women with non-severe HDP, and postpartum monitoring for maternal safety and improvement of long-term cardiovascular health.

These variations arise from limited evidence to drive clinical practice and reflect the reality that many aspects of the guidelines emanate from expert opinion rather than high quality evidence. These are areas requiring further research and consensusbuilding for optimizing management of a high-risk group of women.

Since the main differences are related to the target blood pressure (BP) level, here the arguments for tight and less tight BP control in pregnancy from the AHA scientific statement.

Arguments in favor of a tight BP control in pregnancy First, there are no measurable immediate or longterm health benefits of stricter BP treatment for the relatively short duration of pregnancy (4-9 months, depending on type of HDP) in young women without other CVD risks.

Second, there are concerns that lowering maternal BP may compromise utero-placental circulation and negatively affect fetal well-being and growth.

Third, therapeutic options are limited because of concerns about potential adverse fetal effects, particularly malformations from intrauterine exposure to antihypertensive medications.

\section{Arguments for considering tight BP control}

First, more aggressive treatment of hypertension in pregnancy prevents the development of severe hypertension, as demonstrated by both a systematic review of randomized trials (8) and Control of Hypertension in Pregnancy Study (CHIPS) (9).

Second, there is evidence that the women with preeclampsia may be more susceptible to severe neurological outcomes such as intracerebral hemorrhage at lower systolic BP (e.g, 150-170 mmHg) compared with nonpregnant subjects.

Third, treatment of nonsevere hypertension in pregnancy (e.g, BPs 140-155/90-109 $\mathrm{mmHg}$ ) may permit prolongation of pregnancy in women without other severe features of preeclampsia who would require delivery. 


\begin{tabular}{|c|c|c|}
\hline Parameter & ESC, 2018 & AHA, 2021 \\
\hline $\begin{array}{l}\text { Threshold for the } \\
\text { diagnosis }\end{array}$ & $\begin{array}{l}\text { Office (or in-hospital) SBP } \geq 140 \mathrm{mmHg} \text { and/or } \\
\text { DBP } \geq 90 \mathrm{mmHg}\end{array}$ & $\begin{array}{l}\mathrm{BP} \geq 140 / 90 \mathrm{mmHg} \text {; } \\
2 \text { elevated BP measurements } 4 \text { hours apart. }\end{array}$ \\
\hline Severe hypertension & $\geq 160 / 110 \mathrm{mmHg}$ & $\geq 160 / 110 \mathrm{mmHg}$ \\
\hline $\begin{array}{l}\text { Blood pressure } \\
\text { measurement }\end{array}$ & $\begin{array}{l}\text { Mercury sphygmomanometers; } \\
\text { Oscillometric automatic devices validated in } \\
\text { pregnant women; } \\
\text { Ambulatory BP monitoring is superior to routine } \\
\text { BP measurement for the prediction of } \\
\text { pregnancy outcome. }\end{array}$ & $\begin{array}{l}\text { Mercury sphygmomanometers; } \\
\text { Oscillometric automated devices validated } \\
\text { in pregnant women; } \\
\text { Self-monitoring may be equivalent to } \\
\text { standard clinic thresholds. }\end{array}$ \\
\hline Classification & $\begin{array}{l}\text {-Pre-existing hypertension; } \\
\text {-Gestational hypertension; } \\
\text {-Pre-eclampsia; } \\
\text {-Preexisting hypertension plus superimposed } \\
\text { gestational hypertension with proteinuria; } \\
\text {-Antenatally unclassifiable hypertension }\end{array}$ & $\begin{array}{l}\text {-Preeclampsia/eclampsia; } \\
\text {-Chronic hypertension (of any cause); } \\
\text {-Chronic hypertension with superimposed } \\
\text { preeclampsia; } \\
\text {-Gestational hypertension }\end{array}$ \\
\hline Treatment threshold & $\begin{array}{l}\geq 150 / 95 \mathrm{mmHg} ; \\
>140 / 90 \mathrm{mmHg} \text { in women with: } \\
\text { - gestational hypertension (with or without } \\
\text { proteinuria); } \\
\text { - pre-existing hypertension with the } \\
\text { superimposition of gestational hypertension; } \\
\text { - with subclinical organ damage or symptoms }\end{array}$ & $\begin{array}{l}\geq 160 / 110 \mathrm{~mm} \mathrm{Hg} \text { if acute/chronic } \\
\text { hypertension } \\
\text { Consider lower treatment threshold if co } \\
\text { morbidities or renal failure is present and } \\
\text { to consult with other subspecialties about } \\
\text { BP targets. }\end{array}$ \\
\hline Treatment & $\begin{array}{l}<140 / 90 \mathrm{~mm} \mathrm{Hg} \text {, but noting the optimal } \mathrm{BP} \\
\text { target in pregnancy is unknown }\end{array}$ & 120 \\
\hline Proteinuria & $\begin{array}{l}\text { Dipstick reading of } \geq 1+\text {, should prompt further } \\
\text { investigations: random r urine } \\
\text { albumin/creatinine ratio } \geq 30 \mathrm{mg} / \mathrm{mmol}\end{array}$ & $\begin{array}{l}\geq 300 \mathrm{mg} \text { in a } 24 \text {-hour urine collection or } \\
\text { protein/creatinine ratio } \geq 0.3 \mathrm{mg} / \mathrm{dL} \text { or } \\
\text { Dipstick reading of } 2+\text { (used only if other } \\
\text { quantitative methods not available)( } 6 \text { ) }\end{array}$ \\
\hline $\begin{array}{l}\text { Preeclampsia } \\
\text { diagnosis }\end{array}$ & $\begin{array}{l}\text {-Gestational hypertension with significant } \\
\text { proteinuria; } \\
\text {-Hypertension is accompanied by headache, } \\
\text { visual disturbances, abdominal pain, or } \\
\text { abnormal laboratory tests, specifically low } \\
\text { platelets and/or abnormal liver function. }\end{array}$ & 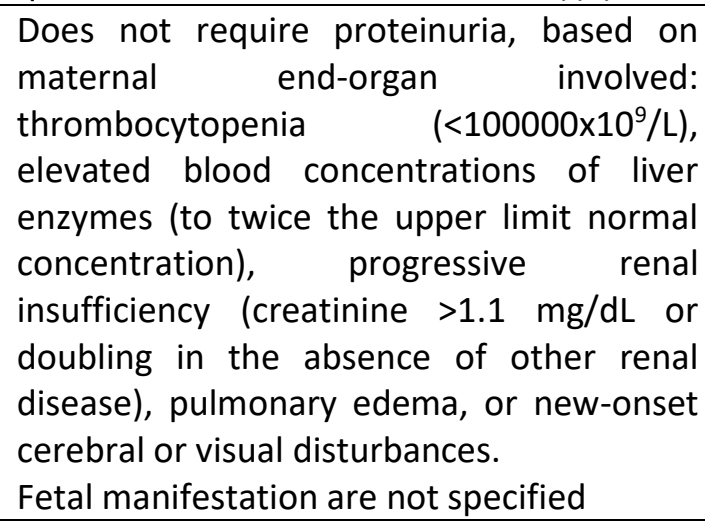 \\
\hline $\begin{array}{l}\text { Superimposed pre- } \\
\text { eclampsia on chronic } \\
\text { hypertension }\end{array}$ & $\begin{array}{l}\begin{array}{l}\text { Hypertension }<20 \text { week of } \\
\text { superimposed } \\
\text { hypertension+proteinuria }\end{array} \\
\text { gestational }\end{array}$ & $\begin{array}{l}\text { Chronic hypertension }+ \text { new proteinuria } \\
\text { after } 20 \text { weeks; sudden substantial and } \\
\text { sustained increase in proteinuria; sudden } \\
\text { increase in BP or need to increase } \\
\text { antihypertensive dose; sudden signs and } \\
\text { symptoms maternal end-organ involved } \\
\text { (see above) }\end{array}$ \\
\hline Treatment threshold & $\geq 140 / 90 \mathrm{mmHg}$ & $\geq 160 / 110 \mathrm{mmHg}$ \\
\hline
\end{tabular}




\begin{tabular}{|c|c|c|}
\hline & & Continued from page .. \\
\hline Parameter & ESC, 2018 & AHA, 2021 \\
\hline Treatment target & $\begin{array}{l}<140 / 90 \mathrm{~mm} \mathrm{Hg} \text {, but noting the optimal BP } \\
\text { target in pregnancy is unknown }\end{array}$ & $\begin{array}{l}\text { Non severe preeclampsia }<160 / 110 \mathrm{~mm} \mathrm{Hg} \\
\text { Chronic hypertension } 120-159 / 80-104 \\
\mathrm{mmHg}\end{array}$ \\
\hline $\begin{array}{l}\text { Urgent treatment of } \\
\text { severe hypertension }\end{array}$ & $\begin{array}{l}\text {-Intravenous labetalol (C), oral methyldopa (B) } \\
\text { or nifedipine (C); } \\
\text {-Intravenous hydralazine; } \\
\text {-Intravenous Uradipil; } \\
\text {-Nitroglycerin when preeclampsia is associated } \\
\text { with pulmonary edema (C). }\end{array}$ & $\begin{array}{l}\text {-Intravenous labetalol (C); } \\
\text {-Intravenous hydralazine; } \\
\text { - nifedipine, immediate release(C); }\end{array}$ \\
\hline $\begin{array}{l}\text { Antihypertensive } \\
\text { treatment }\end{array}$ & $\begin{array}{l}\text { methyldopa (B), labetalol (C), and calcium } \\
\text { antagonists (C) }\end{array}$ & $\begin{array}{l}\text { labetalol (C), methyldopa (B), nifedipine } \\
\text { (C); }\end{array}$ \\
\hline $\begin{array}{lr}\text { Prediction } & \text { and } \\
\text { prevention } & \text { of } \\
\text { preeclampsia } & \end{array}$ & $\begin{array}{l}\text { Screening by high and moderate clinical risk } \\
\text { markers; } \\
\text { Low dose aspirin (100-150 mg daily) is } \\
\text { recommended in women at high or moderate } \\
\text { risk of pre-eclampsia from week } 12 \text { to weeks } \\
36-37 \text {; } \\
\text { Calcium supplementation ( } 1,5-2 \mathrm{~g} / \text { day }) \text { in } \\
\text { women with low dietary intake of calcium } \\
(<600 \mathrm{mg} / \text { day) }\end{array}$ & $\begin{array}{l}\text { Screening by clinical assessment (high, } \\
\text { moderate); } \\
\text { Low-dose aspirin ( } 81 \mathrm{mg} / \text { day) prophylaxis is } \\
\text { recommended in women at high risk of } \\
\text { preeclampsia and should be initiated } \\
\text { between } 12 \text { weeks and } 28 \text { weeks of } \\
\text { gestation (optimally before } 16 \text { weeks) and } \\
\text { continued daily until delivery. }\end{array}$ \\
\hline Delivery & $\begin{array}{l}\text {-Gestational hypertension or mild pre- } \\
\text { eclampsia, delivery is recommended at } 37 \\
\text { weeks; } \\
\text {-Preeclampsia with adverse conditions is } \\
\text { recommended to expedite delivery }\end{array}$ & $\begin{array}{l}\text {-37 weeks gestation for women with } \\
\text { gestational hypertension and preeclampsia } \\
\text { without severe features; } \\
\text {-Women with severe features preeclampsia } \\
\text { should be delivered at } 34 \text { week; } \\
\text {-Indication for earlier delivery (prior to fetal } \\
\text { viability) if maternal end-organ involved (6) }\end{array}$ \\
\hline $\begin{array}{l}\text { Postpartum } \\
\text { hypertension }\end{array}$ & - & $\begin{array}{l}\text { Hypertension (usually mild) that develops } \\
2 \text { weeks to } 6 \text { months postpartum, usually } \\
\text { normalizing by the end of the first year }\end{array}$ \\
\hline $\begin{array}{l}\text { Postpartum CVD risk } \\
\text { management }\end{array}$ & $\begin{array}{l}\text { Annual visits to a primary care physician to } \\
\text { check BP and metabolic factors are } \\
\text { recommended }\end{array}$ & $\begin{array}{l}\text { Postpartum follow-up visit with either the } \\
\text { primary care professional or cardiologist is } \\
\text { recommended within 7-10 days of delivery }\end{array}$ \\
\hline
\end{tabular}

Fourth, ACOG guidelines recommend withholding antihypertensive therapy for patients with preeclampsia unless BP approaches $160 / 110 \mathrm{mmHg}$. They also recommend urgent delivery for women with severe features of preeclampsia, which include uncontrollable hypertension with $B P \geq 160 / 110 \mathrm{mmHg}$, even for pregnancies $<34$ gestational weeks, unless high-level care is available in facilities with adequate maternal and neonatal intensive care resources (10). Lowering thresholds for treatment may allow timely $\mathrm{BP}$ control and avoidance of rushed deliveries that commonly lead to prematurity and related complications.
Fifth, there are current epidemiological and demographic trends toward advanced age at first pregnancy and higher CVD risk (subclinical or diagnosed). This could also be relevant among women with multiple pregnancies, who may spend several years of their lives either pregnant or breastfeeding with uncontrolled hypertension. In addition, modern fertility techniques facilitate pregnancy in women with preexisting conditions associated with elevated CVD risk (diabetes, chronic kidney disease, and polycystic ovary syndrome). Preexisting chronic kidney disease and heart disease are present in $3 \%$ and $1 \%$ to $4 \%$ of pregnancies in high-income countries, respectively (11). 
Finally, there is abundant evidence that HDP are associated with increased risk of both immediate and postpartum complications and future maternal vascular disease. Whether better management of BP during pregnancy will lead to lower rates of morbidity related to hypertension in the immediate postpartum period is not known. It is estimated that approximately two-thirds of HDP-associated CVD risk is mediated by established risk factors, and the remainder is likely explained by an HDP specific pathogenesis (12).

Given the current situation, AHA endorses informed decision-making in partnership with the patient as to whether to treat nonsevere hypertension during pregnancy to targets similar to those recommended in nonpregnant individuals. Personalization of therapy, by giving special attention to other risk factors related to hypertension-related adverse outcomes (such as preexisting heart or kidney disease, obesity, and Black race), is a rational approach.

Management of hypertension in pregnancy requires multidisciplinary collaborations among obstetricians, maternal fetal medicine specialists, neonatologists, nephrologists and hypertension specialists, cardiologists, anesthesiologists, pharmacists, nurses, and midwives, all of whom contribute to providing cohesive and safe preconception, antepartum, peripartum, and postpartum care.

Zhenisgul Tlegenova West Kazakhstan Medical University, Aktobe, Kazakhstan

Peer-review: Internal Conflict of interest: None to declare Authorship: Zh.T. Acknowledgement and funding: None to declare

\section{References}

1.Kassebaum NJ, Barber RM, Bhutta ZA, Dandona L, Gething PW, Hay SI, et al. GBD Global, regional, and national levels of maternal mortality, 1990-2015: a systematic analysis for the Global Burden of Disease Study 2015. Lancet 2016; 388; 1775-812. doi: 10.1016/S0140-6736(16)31470-2

2.Ananth CV, Duzyj CM, Yadava S, Schwebel M, Tita AT, Joseph KS. Changes in the prevalence of chronic hypertension in pregnancy, United States, 1970 to 2010. Hypertension 2019; 74; 1089-95. doi: 10.1161/ HYPERTENSIONAHA.119.12968;
3. Hypertension in pregnancy. Report of the American College of Obstetricians and Gynecologists' Task Force on Hypertension in Pregnancy. Obstet Gynecol 2013; 122: 1122-31. doi: 10.1097/01.AOG.0000437382.03963.88

4.Honigberg MC, Zekavat SM, Aragam K, Klarin D, Bhatt DL, Scott NS, et al. Long-term cardiovascular risk in women with hypertension during pregnancy. J Am Coll Cardiol 2019; 74: 2743-54. doi: 10.1016/j.jacc.2019.09.052

5.Garovic VD, Dechend R, Easterling T, Karumanchi SA, McMurtry Baird S, Magee LA, et al. Hypertension in pregnancy: diagnosis, blood pressure goals, and pharmacotherapy: A Scientific Statement From the American Heart Association. Hypertension 2022; 79: e21-e41. doi: 10.1161/HYP.0000000000000208

6.ACOG Practice Bulletin No. 202: Gestational hypertension and preeclampsia. Obstet Gynecol 2019; 133: 1. doi: 10.1097/AOG.0000000000003018.

7.Regitz-Zagrosek V, Roos-Hesselink JW, Bauersachs J, Blomström-Lundqvist C, Cifkova R, De Bonis $M$, et al. ESC Scientific Document Group. 2018 ESC Guidelines for the management of cardiovascular diseases during pregnancy. Eur Heart J 2018; 39: 3165-241. doi: 10.1093/eurheartj/ehy340.

8.Abalos E, Duley L, Steyn DW, Gialdini C. Antihypertensive drug therapy for mild to moderate hypertension during pregnancy. Cochrane Database Syst Rev 2018; 10: CD002252. doi: 10.1002/14651858.CD002252.pub4

9. Magee LA, von Dadelszen P, Rey E, Ross S, Asztalos $E$, Murphy KE, et al. Less-tight versus tight control of hypertension in pregnancy. N Engl J Med 2015; 372: 407-17. doi: 10.1056/NEJMoa1404595

10.Gestational Hypertension and preeclampsia: ACOG Practice Bulletin Summary, Number 222. Obstet Gynecol 2020; 135: 1492-5. doi: 10.109AOG.0000000000003892

11.Elkayam U, Goland S, Pieper PG, Silverside CK. High-risk cardiac disease in pregnancy: Part I. J Am Coll Cardiol 2016; 68: 396-410. doi: 10.1016/j.jacc.2016.05.048

12. Haug EB, Horn J, Markovitz AR, Fraser A, Klykken B, Dalen $H$, et al. Association of conventional cardiovascular risk factors with cardiovascular disease after hypertensive disorders of pregnancy: analysis of the Nord-Trondelag Health Study. JAMA Cardiol 2019; 4: 628-35. doi: 10.1001/jamacardio.2019.1746. 